\title{
PREDIKSI PRESTASI LOMPAT JAUH GAYA MENGGANTUNG DITINJAU DARI FAKTOR KEMAMPUAN FISIK SISWA PUTRA SMP
}

\author{
Haris Kukuh Triasmono ${ }^{1}$, Sugiyanto ${ }^{2}$, Agus Kristiyanto ${ }^{3}$ \\ 1,2,3 Program Studi IImu Keolahragaan Program Pascasarjana \\ Universitas Sebelas Maret Surakarta. \\ Email : harisson.k49@gmail.com ${ }^{1}$,sugiyantoprobo@gmail.com², \\ aguskriss@yahoo.co.id ${ }^{3}$
}

Diterima: 18 Oktober 2017; Lolos: 14 November 2017; Dipublikasikan: 14 November 2017

\begin{abstract}
Abstrak
Penelitian ini bertujuan untuk menemukan kebenaran tentang faktor kemampuan fisik yang meliputi power otot tungkai, power otot perut, fleksibilitas togok, fleksibilitas punggung, kecepatan dan koordinasi mata kaki dalam memprediksi prestasi lompat jauh gaya menggantung pada siswa putra SMP. Penelitian ini menggunakan pendekatan kuantitatif dengan metode penelitian korelasional. Populasi penelitian ini adalah siswa putra SMP Negeri 2 Bulukerto, jumlah 212 siswa dan sampel 100 siswa, teknik sampling yang digunakan purposive random sampling. Teknik analisis data menggunakan analisis korelasi regresi dengan melakukan pengujian prasyarat uji normalitas dan linieritas. Pengujian hipotesis menggunakan analisis regresi dan korelasi masing-masing prediktor dan analisis regresi ganda serta korelasi ganda. Hasil penelitian menunjukkan bahwa ketika faktor kemampuan fisik secara bersamaan memprediksi prestasi lompat jauh gaya menggantung, maka akan terjadi peningkatan prestasi lompat jauh gaya menggantung sebesar 1.09 untuk setiap peningkatan 1 unit pengukuran power otot tungkai, peningkatan sebesar 0.06 untuk setiap peningkatan 1 unit pengukuran power perut, peningkatan sebesar 0.3 untuk setiap peningkatan 1 unit pengukuran fleksibilitas togok, peningkatan sebesar 0.6 untuk setiap peningkatan 1 unit pengukuran fleksibilitas punggung, peningkatan sebesar 0.3 untuk setiap peningkatan 1 unit pengukuran kecepatan, dan peningkatan sebesar 0.02 untuk setiap peningkatan 1 unit pengukuran koordinasi mata kaki. Kesimpulan dari penelitian ini adalah faktor kemampuan memiliki hubungan dan dapat memprediksi prestasi lompat jauh gaya menggantung.
\end{abstract}

Kata kunci : kemampuan fisik, lompat jauh, gaya menggantung.

\section{PREDICTION OF HANGING STYLE LONG JUMP ACHIEVEMENT REVIEWED FROM PHYSICAL ABILITY FACTOR OF MALE STUDENTS JUNIOR HIGH SCHOOL}
Abstract
This study aims to find out the truth about the factors of physical ability that include leg muscle power, abdominal muscle power, hip flexion, back extension,

\begin{tabular}{cll}
\hline Email & harisson.k49@gmail.com & \\
& sugiyantoprobo@gmail.com & \\
& aguskriss@yahoo.co.id &
\end{tabular}

No Handphone : 087758262888 
speed, and coordination of Eye and Foot in predicting the achievement of long jump style hanging on junior high school students, this research used a purposive random sampling with correlational research method. The population of this research is the students of SMP Negeri 2 Bulukerto is 212 students and the sample is 100 students, the sampling technique used purposive random sampling with several criteria in accordance with the research.. The dependent variable is hang style long jump achievement. Data analysis technique used regression correlation analysis by testing the normality and linearity test prerequisite. Hypothesis testing using regression analysis and correlation of each predictor and multiple regression analysis and multiple correlation. The results showed that when the physical ability factor simultaneously predicted the achievement of hanging style long jump, there would be an increase in the long jump performance of hanging style of 1.09 for each increase of 1 unit measurement of leg muscle power, an increase of 0.06 for each increase of 1 unit measurement of abdominal muscle power, an increase of 0.3 for each increase of 1 unit measurement of hip flexion, an increase of 0.6 for each increase of 1 unit measurement of back extention, an increase of 0.3 for each increase of 1 unit measurement of speed, and an increase of 0.02 for each increase of 1 unit measurement of coordination of eye and foot. The conclusion of this study is that the ability factor has a correlation and can predict the achievement of long jump hanging style.

Keywords: physical ability, long jump, hanging style.

\section{PENDAHULUAN}

Pendidikan Jasmani Olahraga dan Kesehatan merupakan pelajaran yang tidak dapat dipisahkan dari keseluruhan materi pembelajaran di sekolah. Penjasorkes memberikan dampak positif bagi siswa dalam perkembangan kognitif, afektif dan pembentukan psikomotor. Berdasarkan alasan tersebut, pendidikan jasmani olahraga dan kesehatan dimasukkan dalam kurikulum pendidikan nasional. T.C Mutohir \& Lutan (2001: 2) menyatakan, "Pendidikan jasmani merupakan bagian dari pendidikan secara umum. Pendidikan jasmani dapat didefinisikan sebagai suatu proses pendidikan yang ditujukan untuk mencapai tujuan pendidikan melalui gerakan fisik". Dalam pelaksanaan pendidikan jasmani, diajarkan beberapa macam cabang olahraga menurut jenjang pendidikannya.

Atletik merupakan salah satu cabang olahraga yang wajib diberikan di sekolah-sekolah, baik dari tingkat Sekolah Dasar sampai Sekolah Menengah Atas. Hal ini karena atletik merupakan induk dari semua cabang olahraga. Hal ini sesuai pendapat Bahagia dkk., (2005: 1) bahwa; Mengapa cabang olahraga atletik wajib diajarkan di sekolah-sekolah dari 
Sekolah Dasar (SD), Sekolah Lanjutan Tingkat Pertama (SLTP), Sekolah Lanjutan Tingkat Atas (SLTA). Bahkan di beberapa Perguruan Tinggi, atletik sebagai salah satu Mata Kuliah Dasar Umum (MKDU), karena atletik merupakan mothe atau ibu dari semua cabang olahraga. Gerakangerakan yang ada di dalam atletik dimiliki oleh sebagian besar cabangcabang olahraga.

Unsur-unsur dalam atletik adalah jalan, lari, lompat dan lempar. Lompat jauh merupakan salah satu nomor dalam atletik yang wajib diajarkan pada siswa Sekolah Menengah Pertama (SMP). Lompat jauh adalah melompat untuk mencapai hasil sejauh-jauhnya. Kelangsungan gerak pada lompat jauh adalah awalan, tumpuan, posisi saat melayang di udara dan posisi saat mendarat. Di dalam lompat jauh terdiri dari 3 macam gaya yaitu; lompat jauh gaya jongkok, lompat jauh gaya berjalan di udara dan lompat jauh gaya menggantung (bergantung di udara).

Tujuan utama dalam melakukan lompat jauh adalah mencapai jarak lompatan yang sejauh-jauhnya. Untuk mencapai jarak lompatan yang sejauh-jauhnya seorang pelompat harus memiliki kemampuan fisik dan penguasaan teknik yang baik. Oleh sebab itu, Sharkey (2003: 37) aktifitas yang teratur memantapkan fungsi sistem kekebalan, sedangkan aktifitas marathon yang melelahkan bersifat menekan kekebalan sehingga aktifitas yang teratur memiliki kontribusi terhadapkesehatan.

Fisik yang prima merupakan salah satu aset penting yang harus dipertahankan seorang atlet. Faktor fisik berhubungan dengan postur tubuh yang ideal juga berkaitan dengan daya tahan, kecepatan, fleksibilitas, agilitas, koordinasi gerak, dan kekuatan seorang atlet, baik dalam latihan maupun dalam menghadapi pertandingan. Kondisi fisik adalah suatu kesatuan yang utuh dari komponen-komponen yang tidak dapat dipisahkan begitu saja, baik peningkatan maupun pemeliharaannya (Sajoto, 1995: 810).

Lompat jauh merupakan salah satu nomor atletik yang menarik untuk diteliti, karena dari tahun ke tahun pada perlombaan lompat jauh selalu terjadi pemecahan rekor. Dalam perlombaan lompat jauh, seorang 
pelompat akan bertumpu pada balok tumpuan sekuat-kuatnya untuk mendarat di bak lompat sejauh mungkin. Menurut Syarifuddin (1992: 90) lompat jauh adalah suatu bentuk gerakan melompat mengangkat kaki ke atas, ke depan dalam upaya membawa titik berat badan selama (mungkin di udara) yang dilakukan dengan cepat dan dengan jalan melakukan tolakan pada satu kaki untuk mencapai jarak yang sejauh-jauhnya. Karena lompat jauh termasuk nomor lompat yang diperlombakan, maka diperlukan metode latihan yang tepat untuk meningkatkan prestasi.

Lompat jauh merupakan suatu gerakan melompat menggunakan tumpuan satu kaki untuk mencapai jarak sejauh-jauhnya. Sasaran dan tumpuan lompat jauh adalah untuk mencapai jarak lompatan sejauh mungkin ke sebuah letak pendaratan atau bak lompat. Jarak lompatan diukur dari tolakan sampai batas terdekat dari letak pendaratan yang dihasilkan oleh bagian tubuh. Dalam lompat jauh terdapat bermacammacam gaya yang umum dipergunakan oleh para pelompat, yaitu gaya jongkok (tuck), gaya menggantung (hang style), dan gaya jalan di udara (walking in the air). Perbedaan antara gaya lompatan yang satu dengan yang lainnya, ditandai oleh keadaan sikap dan badan waktu melayang di udara. Jadi, mengenai awalan, tumpuan, melayang dan mendarat, bahwa ketiga gaya tersebut prinsipnya sama. Menurut Syarifudin (1992:73), teknik dasar dalam lompat jauh yaitu : (1) Awalan atau ancang-ancang adalah gerakan permulaan untuk mendapatkan kecepatan pada waktu akan melakukan lompatan. Kecepatan yang diperoleh dari hasil awalan ini disebut dengan kecepatan horisontal, yang sangat berguna untuk membantu kekuatan tolakan ke atas, ke depan (pada lompat jauh atau lompat jangkit). (2) Tumpuan/tolakan adalah perubahan atau perpindahan gerakan dari gerakan horisontal ke gerakan vertikal yang dilakukan secara cepat. Tumpuan dapat dilakukan dengan baik dengan menggunakan kaki kiri maupun kanan, tergantung kaki mana yang lebih dominan. (3) Melayang di udara. Sikap badan diudara harus diusahakan melayang selama mungkin di udara serta dalam keadaan seimbang dan yang paling penting pada saat melayang ini adalah melawan rotasi putaran yang 
Haris Kukuh Triasmono ${ }^{1}$, Sugiyanto ${ }^{2}$, Agus Kristiyanto ${ }^{3}$

Prediksi Prestasi Lompat Jauh Gaya Menggantung ditinjau dari Faktor Kemampuan Fisik Siswa Putra SMP

timbul akibat dari tolakan. Selain itu juga untuk mendapatkan posisi mendarat yang paling ekonomis dan efisien. (4) Sikap Mendarat. Melakukan pendaratan adalah bagian akhir dari lompat jauh. Keberhasilan dalam lompat jauh terletak pada pendaratan. Pada pendaratan yang mulus akan berpengaruh terhadap jarak, keselamatan dan keindahan.

Dalam nomor lompat jauh seperti gaya menggantung, perlu didukung oleh komponen-komponen kemampuan fisik yang baik. Furqon (2002: 32) menyatakan "Komponen kondisi fisik dari gerak dasar terdiri dari kecepatan, kekuatan, daya tahan, kelincahan, kelentukan, waktu reaksi, power, koordinasi dan lain-lain". Sedangkan Sudjarwo (1989: 41) berpendapat, "Mempelajari teknik dalam cabang olahraga tertentu tidak mungkin dilakukan sebelum atlet memiliki kemampuan fisik yang menunjang gerakan teknik tersebut".

\section{METODE}

Penelitian ini dilakukan di SMP Negeri 2 Bulukerto Kabupaten Wonogiri. Teknik pengambilan sampel menggunakan teknik purposive random sampling dengan sampel yaitu siswa yang sudah memenuhi syarat sebagai sampel yang dibutuhkan oleh peneliti.

Metode yang akan dipergunakan dalam penelitian ini adalah metode korelasional dengan pendekatan kuantitatif yang mengacu pendapat S. Ali Muhidin dan M. Abdurahman (2009: 105) yang menjelaskan bahwa, tujuan dilakukan metode korelasional antara lain: (1) untuk mencari bukti terdapat tidaknya hubungan (korelasi) antarvariabel, (2) bila sudah ada hubungan, untuk melihat tingkat keeratan hubungan antarvariabel, dan (3) untuk memperoleh kejelasan dan kepastian apakah hubungan tersebut berarti (meyakinkan/signifikan) atau tidak berarti (tidak meyakinkan).

Teknik analisis data dalam penelitian ini dengan menggunakan analisis korelasi regresi dengan melakukan pengujian prasyarat uji normalitas dan linieritas. 
Haris Kukuh Triasmono ${ }^{1}$, Sugiyanto ${ }^{2}$, Agus Kristiyanto ${ }^{3}$

Prediksi Prestasi Lompat Jauh Gaya Menggantung ditinjau dari Faktor Kemampuan Fisik Siswa Putra SMP

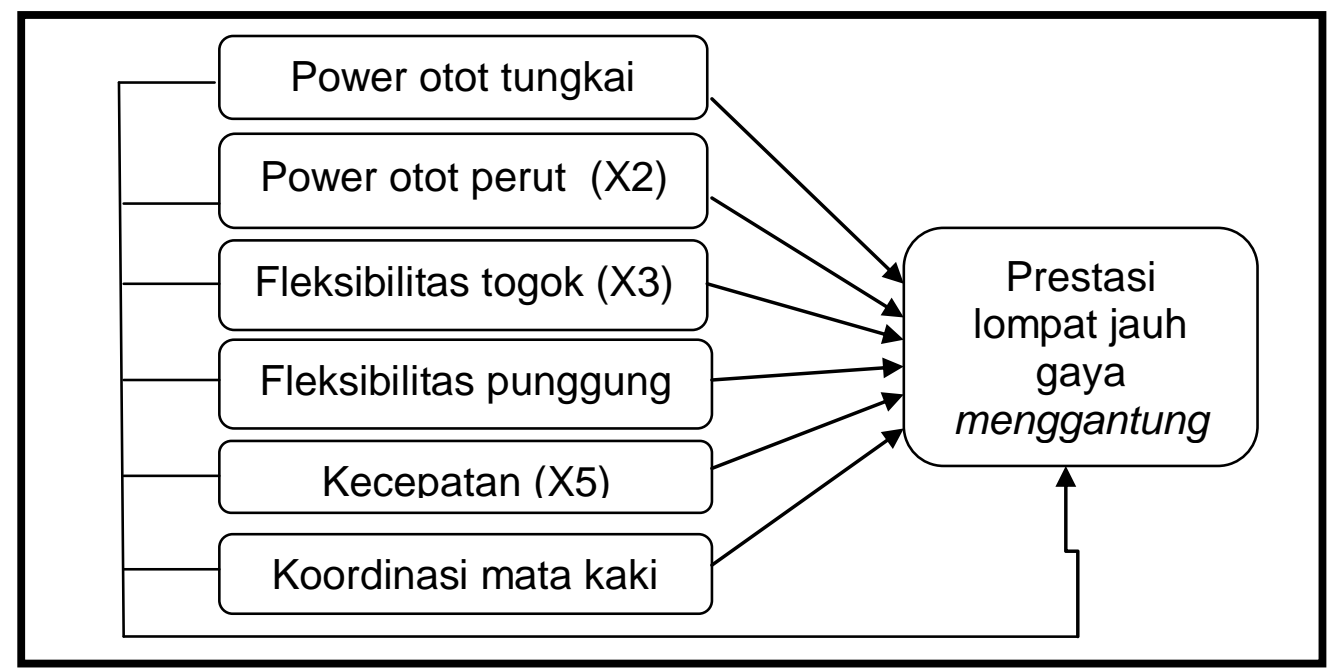

Gambar 1 Rancangan Penelitian

\section{HASIL PENELITIAN}

Tujuan penelitian dapat dicapai dengan pengumpulan data dari masing-masing variabel penelitian. Data yang dikumpulkan dalam penelitian ini terdiri dari 6 variabel bebas yaitu kemampuan fisik, dan satu variabel terikat yaitu prestasi lompat jauh gaya menggantung. Kemudian kemampuan fisik sebagai variabel bebas terdiri atas 6 variabel bebas yaitu power otot tungkai (PT), power otot perut (PP), fleksibilitas togok (FT), fleksibilitas punggung (FP), kecepatan (K) dan koordinasi mata kaki (KK). Deskripsi data yang diperoleh dari tiap-tiap prediktor diperoleh korelasi sebagai berikut : 
Haris Kukuh Triasmono ${ }^{1}$, Sugiyanto ${ }^{2}$, Agus Kristiyanto ${ }^{3}$

Prediksi Prestasi Lompat Jauh Gaya Menggantung ditinjau dari Faktor Kemampuan Fisik Siswa Putra SMP

\section{Prediksi Prestasi Lompat Jauh Gaya Menggantung Ditinjau Dari Faktor Kemampuan Fisik Siswa SMP}

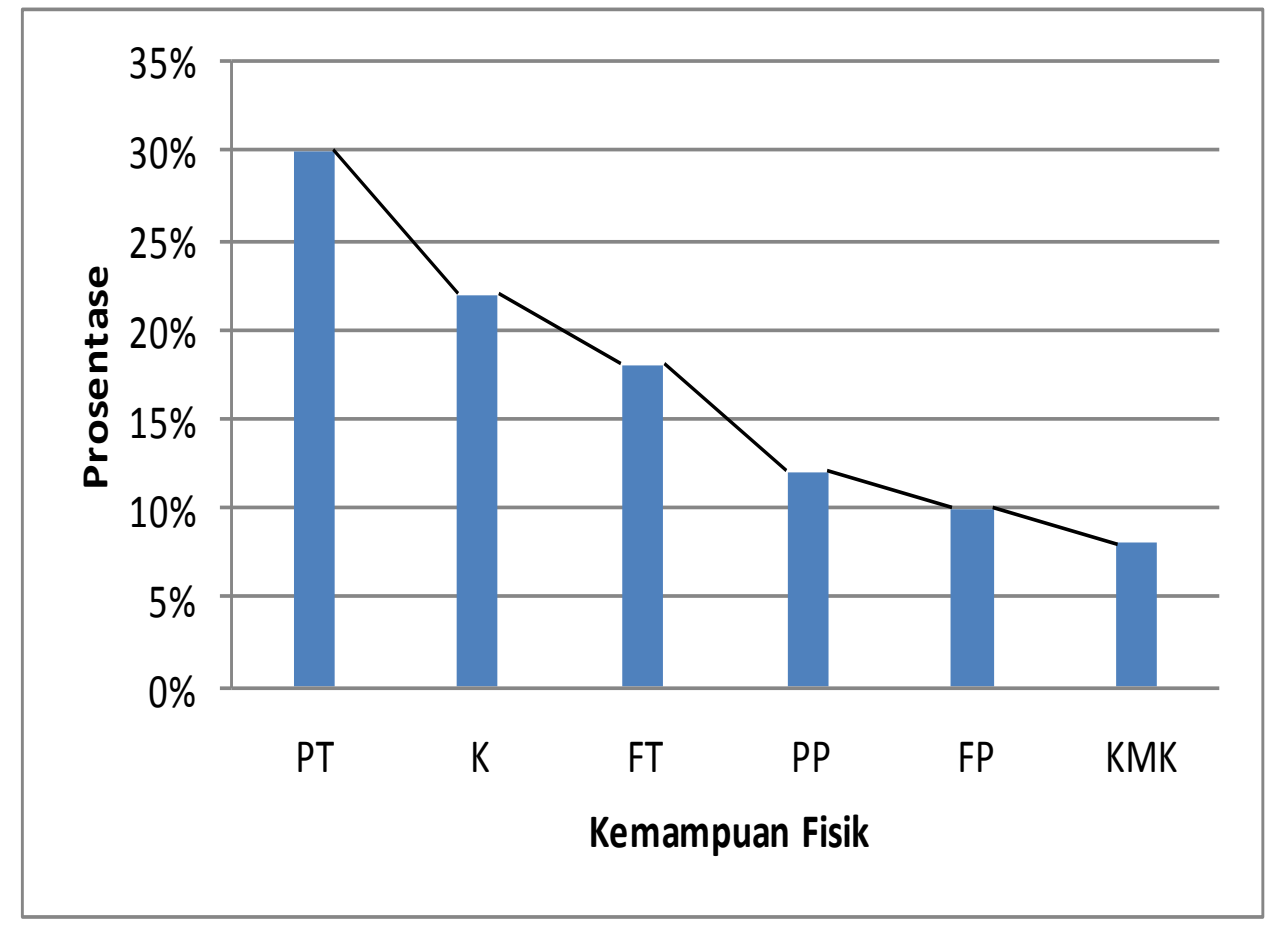

Gambar 2 Prosentase Kemampuan Fisik dalam memprediksi Prestasi Lompat Jauh Gaya Menggantung

\section{PEMBAHASAN}

Tabel 1 Rangkuman Hasil Analisis Regresi Ganda Variabel Kondisi Fisik

\begin{tabular}{|c|c|c|c|c|c|}
\hline \multirow{2}{*}{ Variabel } & \multirow{2}{*}{$\begin{array}{c}\begin{array}{c}\text { Garis } \\
\text { Regresi }\end{array} \\
\mathrm{Y}\end{array}$} & \multirow{2}{*}{$\begin{array}{c}R\left(x_{1}, x_{2}, x_{3,3}, x_{4},\right. \\
\left.x_{5}, x_{6}\right) Y\end{array}$} & \multirow{2}{*}{$R^{2}$} & \multicolumn{2}{|c|}{ Uji Signifikansi } \\
\hline & & & & $\mathrm{F}$ hitung & $\mathrm{F}$ tabel \\
\hline Intersept & 3,5008 & \multirow{7}{*}{0,7425} & \multirow{7}{*}{$55,13 \%$} & \multirow{7}{*}{19,045} & \multirow{7}{*}{2,19} \\
\hline $\mathrm{PT}\left(\mathrm{X}_{1.1}\right)$ & 1,0925 & & & & \\
\hline $\mathrm{PP}\left(\mathrm{X}_{1.2}\right)$ & 0,0582 & & & & \\
\hline $\mathrm{FT}\left(\mathrm{X}_{1.3}\right)$ & 0,306 & & & & \\
\hline $\operatorname{FP}\left(X_{1.4}\right)$ & $-0,0363$ & & & & \\
\hline $\mathrm{PT}\left(\mathrm{X}_{1.5}\right)$ & 0,627 & & & & \\
\hline $\mathrm{DL}\left(\mathrm{X}_{1.6}\right)$ & $-0,0184$ & & & & \\
\hline
\end{tabular}


Haris Kukuh Triasmono ${ }^{1}$, Sugiyanto ${ }^{2}$, Agus Kristiyanto ${ }^{3}$

Prediksi Prestasi Lompat Jauh Gaya Menggantung ditinjau dari Faktor Kemampuan Fisik Siswa Putra SMP

Hasil analisis regresi sederhana prestasi lompat jauh gaya menggantung atas power otot tungkai menghasilkan persamaan regresi : $\hat{Y}=3,55+0,31 X_{1}$. Hal tersebut menunjukan bahwa ketika terjadi perubahan setiap satu unit pengukuran pada variabel power otot tungkai maka akan terjadi perubahan variabel prestasi lompat jauh gaya menggantung sebesar 0,31 meter. Hal tersebut menunjukan bahwa terjadi peningkatan pada variabel keterampilan prestasi lompat jauh gaya menggantung setiap peningkatan satu unit pengukuran variabel power otot tungkai. Nilai uji signifikansi $F_{\text {hitung }}$ sebesar 9,07 dan $F_{\text {tabel }} 3,9361$, hal ini menunjukkan bahwa perubahan variabel prestasi lompat jauh gaya menggantung atas perubahan variabel power otot tungkai signifikan (power otot tungkai dapat menjadi prediktor prestasi lompat jauh gaya menggantung).

Hasil analisis regresi sederhana prestasi lompat jauh gaya menggantung atas power otot perut menghasilkan persamaan regresi : $\hat{Y}$ $=3,31+0,01 X_{2}$. Hal tersebut menunjukan bahwa ketika terjadi perubahan setiap satu unit pengukuran pada variabel power otot perut maka akan terjadi perubahan variabel prestasi lompat jauh gaya menggantung sebesar 0,01. Hal tersebut menunjukan bahwa terjadi peningkatan pada variabel keterampilan prestasi lompat jauh gaya menggantung setiap peningkatan satu unit pengukuran variabel power otot perut. Nilai uji signifikansi $F_{\text {hitung }}$ sebesar 6,18 dan $F_{\text {tabel }} 3,94$, hal ini menunjukkan bahwa perubahan variabel prestasi lompat jauh gaya menggantung atas perubahan variabel power otot tungkai signifikan (power otot perut dapat menjadi prediktor prestasi lompat jauh gaya menggantung).

Hasil analisis regresi sederhana prestasi lompat jauh gaya menggantung atas fleksibilitas togok menghasilkan persamaan regresi : $\hat{Y}$ $=2,35+0,11 \mathrm{X}_{3} \mathrm{Hal}$ tersebut menunjukan bahwa ketika terjadi perubahan setiap satu unit pengukuran pada variabel fleksibilitas togok maka akan terjadi perubahan variabel prestasi lompat jauh gaya menggantung sebesar 0,11. Hal tersebut menunjukan bahwa terjadi peningkatan pada variabel keterampilan prestasi lompat jauh gaya menggantung setiap 
Haris Kukuh Triasmono ${ }^{1}$, Sugiyanto ${ }^{2}$, Agus Kristiyanto ${ }^{3}$

Prediksi Prestasi Lompat Jauh Gaya Menggantung ditinjau dari Faktor Kemampuan Fisik Siswa Putra SMP

peningkatan satu unit pengukuran variabel fleksibilitas togok. Nilai uji signifikansi $F_{\text {hitung }}$ sebesar 29,98 dan $F_{\text {tabe/ }} 3,94$, hal ini menunjukan bahwa perubahan variabel prestasi lompat jauh gaya menggantung atas perubahan variabel fleksibilitas togok signifikan (fleksibilitas togok dapat menjadi prediktor prestasi lompat jauh gaya menggantung).

Hasil analisis regresi sederhana prestasi lompat jauh gaya menggantung atas fleksibilitas punggung menghasilkan persamaan regresi : $\hat{Y}=3,54+0,01 \mathrm{X}_{4} \mathrm{Hal}$ tersebut menunjukan bahwa ketika terjadi perubahan setiap satu unit pengukuran pada variabel fleksibilitas punggung maka akan terjadi perubahan variabel prestasi lompat jauh gaya menggantung sebesar 0,01 . Hal tersebut menunjukan bahwa terjadi peningkatan pada variabel keterampilan prestasi lompat jauh gaya menggantung setiap peningkatan satu unit pengukuran variabel fleksibilitas punggung. Nilai uji signifikansi $F_{\text {hitung }}$ sebesar 7,16 dan $F_{\text {tabel }}$ 3,94 , hal ini menunjukan bahwa perubahan variabel prestasi lompat jauh gaya menggantung atas perubahan variabel fleksibilitas punggung signifikan (fleksibilitas punggung dapat menjadi prediktor prestasi lompat jauh gaya menggantung).

Hasil analisis regresi sederhana prestasi lompat jauh gaya menggantung atas kecepatan menghasilkan persamaan regresi : $\hat{Y}=5,19$ $-0,13 \mathrm{X}_{5} \mathrm{Hal}$ tersebut menunjukan bahwa ketika terjadi perubahan setiap satu unit pengukuran pada variabel kecepatan maka akan terjadi perubahan variabel prestasi lompat jauh gaya menggantung sebesar 0,13. Hal tersebut menunjukan bahwa terjadi peningkatan pada variabel keterampilan prestasi lompat jauh gaya menggantung setiap peningkatan satu unit pengukuran variabel kecepatan. Nilai uji signifikansi $F_{\text {hitung }}$ sebesar 5,84 dan $F_{\text {tabel }} 3,94$, hal ini menunjukan bahwa perubahan variabel prestasi lompat jauh gaya menggantung atas perubahan variabel kecepatan signifikan (kecepatan dapat menjadi prediktor prestasi lompat jauh gaya menggantung).

Hasil analisis regresi sederhana prestasi lompat jauh gaya menggantung atas Koordinasi mata kaki menghasilkan persamaan regresi 
Haris Kukuh Triasmono ${ }^{1}$, Sugiyanto ${ }^{2}$, Agus Kristiyanto ${ }^{3}$

Prediksi Prestasi Lompat Jauh Gaya Menggantung ditinjau dari Faktor Kemampuan Fisik Siswa

Putra SMP

$: \hat{Y}=3,65+0,02 X_{6}$ Hal tersebut menunjukan bahwa ketika terjadi perubahan setiap satu unit pengukuran pada variabel koordinasi mata kaki maka akan terjadi perubahan variabel prestasi lompat jauh gaya menggantung sebesar 0,02. Hal tersebut menunjukan bahwa terjadi peningkatan pada variabel keterampilan prestasi lompat jauh gaya menggantung setiap peningkatan satu unit pengukuran variabel koordinasi mata kaki. Nilai uji signifikansi $F_{\text {hitung }}$ sebesar 10,03 dan $F_{\text {tabel }} 3,94$, hal ini menunjukan bahwa perubahan variabel prestasi lompat jauh gaya menggantung atas perubahan variabel koordinasi mata kaki signifikan (koordinasi mata kaki dapat menjadi prediktor prestasi lompat jauh gaya menggantung).

\section{KESIMPULAN DAN SARAN}

\section{Kesimpulan}

Apabila terjadi peningkatan satu unit pengukuran pada power otot tungkai maka akan terjadi peningkatan prestasi lompat jauh gaya menggantung.

Apabila terjadi peningkatan satu unit pengukuran pada power otot perut maka akan terjadi peningkatan prestasi lompat jauh gaya menggantung.

Apabila terjadi peningkatan satu unit pengukuran pada fleksibilitas togok maka akan terjadi peningkatkan prestasi lompat jauh gaya menggantung.

Apabila terjadi peningkatan satu unit pengukuran pada fleksibilitas punggung maka akan terjadi peningkatan prestasi lompat jauh gaya menggantung.

Apabila terjadi peningkatan satu unit pengukuran pada kecepatan maka akan terjadi peningkatan prestasi lompat jauh gaya menggantung.

Apabila terjadi peningkatan satu unit pengukuran pada koordinasi mata kaki maka akan terjadi peningkatan prestasi lompat jauh gaya menggantung. 
Haris Kukuh Triasmono ${ }^{1}$, Sugiyanto ${ }^{2}$, Agus Kristiyanto ${ }^{3}$

Prediksi Prestasi Lompat Jauh Gaya Menggantung ditinjau dari Faktor Kemampuan Fisik Siswa Putra SMP

\section{Saran}

Pelatih atlet lompat jauh hendaknya mampu memaksimalkan kemampuan fisik yang dimiliki oleh anak didiknya, sehingga prestasi lompat jauhnya menjadi maksimal. Selain itu guna meningkatkan kondisi fisik anak didik, pelatih hendaknya senantiasa melakukan kegiatan latihanlatihan yang intensif dengan metode-metode yang akurat sehingga mampu meningkatkan kondisi fisik anak didik dengan sebaik-baiknya guna mendukung prestasi lompat jauh anak didik.

Dalam latihan untuk mencapai prestasi lompat jauh gaya menggantung hendaknya dilakukan berdasarkan faktor kemampuan fisik yang memiliki hubungan dengan prestasi lompat jauh gaya menggantung tersebut. Faktor kemampuan fisik yang dapat memprediksi prestasi lompat jauh gaya menggantung dari yang paling besar yaitu power otot tungkai, kecepatan, fleksibilitas togok, power otot perut, fleksibilitas punggung, dan koordinasi mata kaki.

Setelah diketahui tentang kemampuan memprediksi dari faktor kemampuan fisik, atlet dapat meningkatkan kemampuan fisiknya sesuai dengan kemampuan yang dimiliki. Tujuan akhirnya adalah atlet mampu untuk menguasai keterampilan yang baik sehingga pada saat atlet melakukan lompat jauh gaya menggantung dengan maksimal.

Bagi peneliti lain diharapkan dapat memperhatikan faktor kemampuan fisik lain dan faktor lain selain faktor kemampuan fisik yang memiliki hubungan dan dapat memprediksi prestasi lompat jauh gaya menggantung.

\section{DAFTAR PUSTAKA}

Adisasmita, Y \& Syarifuddin, A. 1996. IImu Kepelatihan Dasar. Jakarta: Depdikbud. Dirjen dikti.Proyek Pendidikan Tingkat Akademik.

Bahagia, Y, Yusuf, U \& Suherman, A. 2000. Atletik. Jakarta: Depdiknas

M. Furqon H. 2000. Pengembangan Bakat Olahraga. Surakarta: Pusat Penelitian Keolahragaan (Puslibang-OR) UNS.

Muhidin, A S \& Maman, A. 2009. Analisis Korelasi, Regresi, dan Jalur Dalam Penelitian. Bandung: Pustaka Setia 
Haris Kukuh Triasmono ${ }^{1}$, Sugiyanto ${ }^{2}$, Agus Kristiyanto ${ }^{3}$

Prediksi Prestasi Lompat Jauh Gaya Menggantung ditinjau dari Faktor Kemampuan Fisik Siswa

Putra SMP

Mutohir, T C, Maksum \& Ali. 2007. Sport Development Index (Konsep Metodologi dan Aplikasi). Jakarta: PT. Indeks.

Sajoto, M. 1995. Peningkatan dan Pembinaan Kondisi Fisik Dalam Olahraga. Semarang: Dahara Prize.

Sharkey, B.J. 2003. Kebugaran dan Kesehatan. Cetakan pertama. Penerbit PT Raja Grafindo Persada, Jakarta. Hal 34.

Sudjarwo. 1989. Beberapa Aspek Pengembangan Sumber Belajar. (Jakarta: PT Mediyatama Sarana Perkasa) 